\title{
Retraction Note to: Influence of coastal beach stability based on stochastic simulation method and English translation of import product vocabulary
}

\section{Xiuping Geng ${ }^{1}$}

Published online: 3 November 2021

(c) Saudi Society for Geosciences 2021

Retraction Note to: Arabian Journal of Geosciences (2021) 14: 1537 https://doi.org/10.1007/s12517-021-07925-3

The Editor-in-Chief and the Publisher have retracted this article because the content of this article is nonsensical. The peer review process was not carried out in accordance with the Publisher's peer review policy. The author has not responded to correspondence regarding this retraction.

Publisher's note Springer Nature remains neutral with regard to jurisdictional claims in published maps and institutional affiliations.

The original article can be found online at https://doi.org/10.1007/ s12517-021-07925-3.

Xiuping Geng

nancygxp996@126.com

1 College of Foreign Languages, Baoji University of Arts and Sciences, Baoji, Shaanxi, China 